\title{
Hepatitis B, C, and Delta in the General Population in Mayotte: Hepatitis B as a Major Public Health Concern
}

Cécile Brouard ( $\nabla$ cecile.brouard@santepubliquefrance.fr )

Santé publique France, the National Public Health Agency, HIV, Hepatitis B/C and STI Unit

\section{Fanny Parenton}

Santé publique France, the National Public Health Agency, Mayotte Regional Office

Hassani Youssouf

Santé publique France, the National Public Health Agency, Mayotte Regional Office

\section{Stéphane Chevaliez}

National Reference Centre for Viral Hepatitis B, C and Delta, Henri Mondor University Hospital

\section{Emmanuel Gordien}

National Reference Centre for Viral Hepatitis B, C and Delta, Paris-Seine-Saint- Denis University Hospitals

\section{Maxime Jean}

Mayotte Health Regional Agency

\section{Mathias Bruyand}

Santé publique France, the National Public Health Agency, HIV, Hepatitis B/C and STI Unit

\section{Sophie Vaux}

Santé publique France, the National Public Health Agency, HIV, Hepatitis B/C and STI Unit

\section{Florence Lot}

Santé publique France, the National Public Health Agency, HIV, Hepatitis B/C and STI Unit

\section{Marc Ruello}

Santé publique France, the National Public Health Agency, Survey Unit

\section{Unono Wa Maore group}

Santé publique France, the National Public Health Agency, France

\section{Research Article}

Keywords: Hepatitis B, hepatitis C, hepatitis delta, prevalence, Mayotte, general population

Posted Date: February 23rd, 2022

DOI: https://doi.org/10.21203/rs.3.rs-1238218/v1

License: () (i) This work is licensed under a Creative Commons Attribution 4.0 International License. Read Full License 


\section{Abstract \\ Background}

In the 15-69-year-old general population living in Mayotte, we estimated the prevalence of infections by hepatitis B (HBV), $\mathrm{C}(\mathrm{HCV})$, and delta (HDV) viruses and the distribution of HBV status: current infection with positive $\mathrm{HBs}$ antigen (Ag); resolved infection with positive $\mathrm{HBc}$ antibodies and negative $\mathrm{HBsAg}$; immunisation by vaccination with only positive HBs antibodies; and no infection/no immunisation with negative markers. We described the characteristics of infected people. We also assessed the determinants of HBV infection.

\section{Methods}

The Unono Wa Maore survey, implemented in a random sample of the general population in 2018-2019, consisted of an at-home collection of epidemiological data and venous blood samples. Detection of hepatitis B, C, and delta serological and molecular markers was performed. Determinants of lifetime HBV infection were assessed using Poisson regression models.

\section{Results}

Among 5,207 eligible people, 4,643 responded to the questionnaire (89.2\%), with 2,917 being tested for HBV and HCV (62.8\%). Estimated HBV status was as follows: current infection 3.0\% (95\% confidence interval [Cl]: $2.3-3.9 \%)(n=76)$; resolved infection $27.8 \%$ (95\% Cl: $25.8-29.9)$; immunisation by vaccination $27.7 \%$ (95\% Cl: $25.9-29.7)$; and no infection/no immunisation $41.5 \%(95 \% \mathrm{Cl}$ : 39.3-43.7). One participant was positive for HDV antibodies (Ab) (0.65\%) with a negative HDV-RNA viral load. The risk of lifetime HBV infection was higher in men (adjusted prevalence ratio (aPR): $1.55,95 \% \mathrm{Cl}$ : 1.29-1.89); in people aged 30-49 years (aPR: $3.83,95 \% \mathrm{Cl}: 1.49-9.81$ ) or 50-69 years (aPR: $4.52,95 \% \mathrm{Cl}: 1.77-11.53$ ) compared to those under 20; in individuals who reported no condom use during their first sexual intercourse (aPR: 1.46, 95\% Cl: 1.01-2.14); and in those living in Dembeni-Mamoudzou (aPR: 1.40, 95\% Cl: 1.09-1.80) compared to the WestCentre of Mayotte. Finally, six individuals were positive for HCV antibodies (0.21\%), including three positive for HCV RNA.

\section{Conclusions}

Mayotte is an area of intermediate endemicity for HBV and low endemicity for HCV and HDV. With a prevalence of HBsAg 10 times higher than in mainland France, a high proportion of people susceptible to HBV infection, and a demographic, health, and social context that may favour its transmission, hepatitis B is a major public health concern in Mayotte.

\section{Background}

Located in the Comoros archipelago in the southwestern Indian Ocean, Mayotte is the smallest French territory (376 km2), though with the highest population density (768 inhabitants $/ \mathrm{km}^{2}$ ) after lle-de-France (Paris region) [1]. Estimated at 288,926 inhabitants (on January 1, 2021), the population is very young, with $53.8 \%$ being under 20 years [1]. Mayotte has experienced strong demographic growth $(+3.8 \%$ on average per year since 2012) [2], mainly linked to a very high birth rate (35.2\% vs $10.7 \%$ o for mainland France) [3] and high levels of immigration, mainly from the Comoros [2]. Consequently, almost half of the population living in Mayotte (48\%) is of foreign nationality [2]. The social situation is quite unfavourable, with $77 \%$ of the population living below the poverty line (vs $14 \%$ in mainland France), often in precarious housing conditions ( $60 \%$ of dwellings lack running water, toilets, and showers) [4]. The health context is also worrying with limited health care services (e.g., the density of general practitioners is six times lower than elsewhere in France [5]), in a 
context marked by high frequencies of chronic diseases (especially, cardiovascular) [6, 7] or infectious diseases [8,9] as well as insufficient vaccine coverage [10].

To date, epidemiological data on hepatitis B and C in Mayotte have been sparse and tend to focus on specific populations. The prevalence of hepatitis $B$ surface antigen ( $\mathrm{HBsAg})$, indicating current infection with the hepatitis $B$ virus (HBV), was estimated between $2.3 \%$ and $4.8 \%$ in pregnant women according to various studies carried out between 2008 and 2016 [11-14], i.e., a prevalence three to six times higher than estimated in the same population in France in 2016 (0.84\%) [12]. HBsAg prevalence was 4.3\% among patients hospitalised in Mamoudzou Hospital Centre (CHM) in 20142015 [15]. In 2016, the positivity rate of HBsAg tests performed at CHM was $3.8 \%$ versus $0.8 \%$ in France [16]. For hepatitis C virus (HCV), among 697 patients hospitalised at CHM in 2014-2015, seven (1\%) had HCV antibodies (HCV Ab), of which three had a current infection (positive HCV-RNA) [15]. The positivity rate of HCV Ab tests performed at the CHM was $0.03 \%$ versus $0.7 \%$ in France in 2016 [16]. For hepatitis delta virus (HDV), there are no published data.

In the 15-69-year-old general population living in Mayotte, our objectives were as follows: 1) to estimate the prevalence of infections by HBV, HCV, and HDV and the distribution of HBV infection status according to epidemiological characteristics; 2) to describe the epidemiological and virological characteristics of infected people; and 3) to identify the sociodemographic and behavioural determinants of HBV infection.

\section{Methods}

\section{Study design}

We analysed the data of Unono Wa Maore, a cross-sectional health survey conducted from November 2018 to June 2019 in a random sample of the general population aged under 70 years and living in Mayotte for at least 3 months [17]. Sampling used a three-degree survey plan: random selection of addresses, households (if several dwellings at the same address), and persons living in the selected household with a maximum of three people aged 15-69 years.

\section{Data collection}

After obtaining informed consent, data collection consisted of face-to-face interviews performed at participants' homes by trained investigators. Two standardised questionnaires were used for participants aged 15 to 69 years: a 45-minute questionnaire (long questionnaire) for the first person of the household, and a short 15-minute questionnaire for the other people. The data collected focussed on socio-demographic characteristics, health situation (diet, diabetes, consumption of psychoactive substances, vector-borne diseases, etc.), recourse to health care, sexuality, preventive behaviour, and especially history of anti-HBV vaccination, HIV screening and history of HCV or HBV diagnosis.

Venous blood samples and anthropometric measurements were performed at home by a nurse in participants aged 1569 years.

\section{Laboratory testing}

Detection of HBsAg, total HBc Ab, HBs Ab, and HCV Ab was performed using the Architect HBsAg Qualitative II, Anti-HBc II, Anti-HBs, and Anti-HCV kits, respectively, on the Architect device (Abbott Diagnostics, Des Plaines, IL). In HBsAg positive samples, the following analyses were carried out: determination of HBe status (LIAISON HBeAg/Anti-HBe, DiaSorin), detection/quantification of HBV-DNA (Alinity HBV m, Abbott), determination of HBV genotype (phylogenetic analysis of the S/P region), detection of HDV Ab (LIAISON XL Murex Anti-HDV and/or HDV Ab-ELISA-Dia.pro), and if positive, detection/quantification of HDV-RNA and determination of HDV genotype (R0 region phylogeny, CNR Delta technique). In samples positive for HCV Ab, detection/quantification of HCV-RNA (Alinity $\mathrm{m} \mathrm{HCV}$, Abbott) and determination of HCV genotype (Sentosa SQ HCV Genoptyping Assay v2) were performed. 
Detection of HIV antibodies was also carried out (Architect HIV Ag/Ab Combo), with positive samples confirmed by Western blot. The level of glycated haemoglobin ( $\mathrm{HbA1c}$ ) was measured by high performance liquid chromatography.

\section{Definitions}

HBV infection status was classified using serological status as follows: current infection, resolved infection, immunisation by vaccination, and no infection/no immunisation (Table 1). Lifetime HBV infection was defined by a current or resolved infection, that is, positive HBc antibodies regardless HBsAg. The cut-off considered for HBs antibody positivity was 10 $\mathrm{mIU} / \mathrm{mL}$.

Table 1

Definition of HBV infection status

\begin{tabular}{|llll|}
\hline \multicolumn{4}{|l|}{ HBV serological markers } \\
\hline HBV infection status & HBsAg & HBc Ab & HBs Ab \\
\hline Current infection & + & $+/-$ & $+/-$ \\
\hline Resolved infection & - & + & $+/-$ \\
\hline Immunisation by vaccination & - & - & + \\
\hline No infection/no immunisation & - & - & - \\
\hline HBC Ab: HBc antibodies; HBs Ab: HBs antibodies; HBsAg: HBs antigen; HBV: Hepatitis B virus; +: positive; $:$ negative \\
\hline
\end{tabular}

Obesity was defined by a body mass index of at least $30 \mathrm{~kg} / \mathrm{m}^{2}$. Individuals were considered to have diabetes if a doctor had already diagnosed them with diabetes or if their $\mathrm{HbA} 1 \mathrm{c}$ level was at least $6.5 \%$.

Precarious housing was defined as a construction that was not solid or lacking running water or toilets in the dwelling.

In accordance with the administrative division of Mayotte, the 17 municipalities were grouped into five inter-municipalities (Dembéni-Mamoudzou, North, West-Centre, Petite-Terre, and South) [18].

\section{Data analysis}

Data analysis concerned participants aged between 15 and 69 years.

The prevalence of HBV and HCV infections was estimated as the proportion of people who tested positive among those tested and then extrapolated to the general population living in Mayotte.

Comparisons were made using the Chi-square test for qualitative variables with a significance level of $5 \%$.

Poisson regression models were used to assess the determinants of current HBV infection. To maximise the power, this analysis included all participants screened for HBV and was adjusted for the variables common to the long and short questionnaires. Poisson regression models were also used for lifetime HBV infection. This analysis included participants screened for HBV who had completed the long questionnaire to allow for adjustments to the variables only included in this questionnaire (e.g., place of birth, sexual behaviour).

Variables included in the multivariate models had at least one category with a $P$-value $<0.20$ in univariate analysis. The threshold of 0.05 was considered statistically significant in multivariate analyses.

The results were weighted and adjusted to take into account sampling and non-responses at both the household and individual levels [17]. 


\section{Results}

\section{Participant and population characteristics}

Among the 5,069 selected households, 3,561 were exploitable (70.3\%) of which 2,600 households (73.0\%) participated in the survey (Fig. 1) [17]. In these households, 5,207 people aged 15-69 years were invited to participate, with 4,643 (89.2\%) answering the short $(n=2,248)$ or long $(n=2,395)$ questionnaires. Among them, 2,917 people were tested for HBV and HCV serological markers (62.8\%): 1,412 and 1,505 of these tested participants answered the short and long questionnaires, respectively.

\section{HBV: Hepatitis B virus; HCV: Hepatitis C virus}

After weighting, the distributions of the main socio-demographic and epidemiological characteristics of participants tested for HBV and HCV were similar to those of all participants, except for place of birth, as $49.4 \%$ of screened participants were born in the Comoros compared to $46.7 \%$ of all participants (Table 2 ). 
Table 2

Socio-demographic and epidemiological characteristics of participants screened for HBV and HCV compared to all participants in the Unono Wa Maore survey, Mayotte, 2018-2019

\begin{tabular}{|c|c|c|c|c|c|}
\hline & \multicolumn{3}{|c|}{$\begin{array}{l}\text { Participants screened for HBV/HCV }(n= \\
2,917)\end{array}$} & \multicolumn{2}{|c|}{$\begin{array}{l}\text { All survey participants } \\
(n=4,643)\end{array}$} \\
\hline & $\mathbf{n}$ & Raw \% & Weighted \% & $\mathbf{n}$ & $\begin{array}{l}\text { Weighted } \\
\%\end{array}$ \\
\hline \multicolumn{6}{|l|}{ Gender } \\
\hline Men & 1,074 & $36.8 \%$ & $46.0 \%$ & 1,856 & $46.0 \%$ \\
\hline Women & 1,843 & $63.2 \%$ & $54.0 \%$ & 2,787 & $54.0 \%$ \\
\hline \multicolumn{6}{|l|}{ Age (years) } \\
\hline $15-19$ & 519 & $17.8 \%$ & $18.4 \%$ & 848 & $18.3 \%$ \\
\hline $20-29$ & 585 & $20.0 \%$ & $23.9 \%$ & 938 & $24.0 \%$ \\
\hline $30-49$ & 1,277 & $43.8 \%$ & $43.3 \%$ & 2,018 & $43.0 \%$ \\
\hline $50-69$ & 536 & $18.4 \%$ & $14.4 \%$ & 839 & $14.7 \%$ \\
\hline \multicolumn{6}{|l|}{ Place of birth ${ }^{1}$} \\
\hline Mayotte & 576 & $38.3 \%$ & $42.5 \%$ & 1,021 & $45.1 \%$ \\
\hline Comoros & 789 & $52.5 \%$ & $49.4 \%$ & 1,134 & $46.7 \%$ \\
\hline France excluding Mayotte & 32 & $2.1 \%$ & $1.8 \%$ & 68 & $2.4 \%$ \\
\hline Other countries & 107 & $7.1 \%$ & $6.3 \%$ & 168 & $5.8 \%$ \\
\hline \multicolumn{6}{|l|}{ Place of residence } \\
\hline Dembeni-Mamoudzou & 1,334 & $45.7 \%$ & $34.5 \%$ & 1,899 & $34.1 \%$ \\
\hline North & 233 & $8.0 \%$ & $20.2 \%$ & 650 & $21.9 \%$ \\
\hline West-Centre & 571 & $19.6 \%$ & $20.5 \%$ & 953 & $19.8 \%$ \\
\hline Petite-Terre & 474 & $16.2 \%$ & $13.4 \%$ & 630 & $12.5 \%$ \\
\hline South & 305 & $10.5 \%$ & $11.4 \%$ & 511 & $11.7 \%$ \\
\hline \multicolumn{6}{|l|}{ Educational level } \\
\hline No diploma & 1,815 & $63.6 \%$ & $60.8 \%$ & 2,747 & $58.7 \%$ \\
\hline$<$ Secondary school certificate & 760 & $26.6 \%$ & $27.5 \%$ & 1,262 & $29.2 \%$ \\
\hline Secondary school certificate or higher & 279 & $9.8 \%$ & $11.7 \%$ & 515 & $12.1 \%$ \\
\hline \multicolumn{6}{|l|}{ Health insurance coverage ${ }^{1}$} \\
\hline None & 573 & $38.2 \%$ & $36.5 \%$ & 850 & $35.9 \%$ \\
\hline Social security only & 817 & $54.4 \%$ & $56.1 \%$ & 1,314 & $56.0 \%$ \\
\hline $\begin{array}{l}\text { Social security and complementary } \\
\text { insurance }\end{array}$ & 111 & $7.4 \%$ & $7.4 \%$ & 217 & $8.1 \%$ \\
\hline Precarious housing & & & & & \\
\hline
\end{tabular}




\begin{tabular}{|c|c|c|c|c|c|}
\hline & \multicolumn{3}{|c|}{$\begin{array}{l}\text { Participants screened for HBV/HCV }(n= \\
2,917)\end{array}$} & \multicolumn{2}{|c|}{$\begin{array}{l}\text { All survey participants } \\
(n=4,643)\end{array}$} \\
\hline & $\mathbf{n}$ & Raw \% & Weighted \% & $\mathbf{n}$ & $\begin{array}{l}\text { Weighted } \\
\%\end{array}$ \\
\hline Yes & 1,706 & $58.5 \%$ & $57.7 \%$ & 2,549 & $57.3 \%$ \\
\hline No & 1,211 & $41.5 \%$ & $42.3 \%$ & 2,094 & $42.7 \%$ \\
\hline \multicolumn{6}{|l|}{ Living in couple } \\
\hline Yes & 1,649 & $56.6 \%$ & $57.2 \%$ & 2,640 & $57.4 \%$ \\
\hline No & 1,267 & $43.4 \%$ & $42.8 \%$ & 1,999 & $42.6 \%$ \\
\hline \multicolumn{6}{|l|}{ Lifetime sexual relations $^{1}$} \\
\hline Yes & 1,318 & $88.1 \%$ & $82.8 \%$ & 2,087 & $82.9 \%$ \\
\hline No & 178 & $11.9 \%$ & $17.2 \%$ & 293 & $17.1 \%$ \\
\hline \multicolumn{6}{|l|}{$\begin{array}{l}\text { Condom use during first sexual } \\
\text { intercourse }^{1,2}\end{array}$} \\
\hline Yes & 172 & $15.6 \%$ & $18.8 \%$ & 294 & $19.5 \%$ \\
\hline No & 927 & $84.4 \%$ & $81.2 \%$ & 1,445 & $80.5 \%$ \\
\hline \multicolumn{6}{|l|}{ Perceived health condition } \\
\hline Excellent/very good/good & 1,339 & $46.9 \%$ & $48.8 \%$ & 2,215 & $50.1 \%$ \\
\hline Intermediate & 1,015 & $35.6 \%$ & $34.8 \%$ & 1,572 & $34.4 \%$ \\
\hline Poor/very poor & 498 & $17.5 \%$ & $16.4 \%$ & 749 & $15.5 \%$ \\
\hline \multicolumn{6}{|l|}{ Reported HBV vaccine status } \\
\hline Vaccinated & 892 & $30.6 \%$ & $32.1 \%$ & 1,500 & $33.0 \%$ \\
\hline Not vaccinated & 407 & $13.9 \%$ & $14.5 \%$ & 651 & $14.6 \%$ \\
\hline Not specified & 1,618 & $55.5 \%$ & $53.4 \%$ & 2,492 & $52.4 \%$ \\
\hline
\end{tabular}

1 These questions were only included in the long questionnaire ( $n=1,505$ for participants screened for $\mathrm{HBV} / \mathrm{HCV} ; n=$ 2,395 for survey participants aged between 15 and 69 years).

2 Among individuals who reported having sexual relations in their lifetime.

\section{Hepatitis B and delta}

HBV serological status was available for 2,916 participants (HBsAg result was missing for one person). HBV infection status was significantly associated with all socio-demographic and epidemiological characteristics studied in univariate analysis (Fig. 2).

\section{Current HBV infection}

Overall, 76 participants tested positive for HBsAg, corresponding to an estimated prevalence of current HBV infection of $3.0 \%$ (95\% confidence interval [Cl]: 2.3-3.9) in the general population aged 15 to 69 years and living in Mayotte (Fig. 2). The prevalence was twice as high in men than in women ( $4.3 \%$ vs $\left.1.9 \%, p<10^{-2}\right)$ and was highest in those aged $30-49$ 
years (4.1\%). It was significantly higher in people living in couples (3.8\% vs $\left.1.9 \%, p<10^{-2}\right)$ and in those who declared no condom use during their first sexual intercourse compared to those who indicated using one $(3.9 \%$ vs $0.7 \%, p<0.05)$.

In multivariate analysis, men had an increased risk of having a current HBV infection (adjusted prevalence ratio [aPR]: 2.35 (95\% Cl: 1.38-4.00)), as did individuals aged 20-29 (aPR: 3.89 (95\% Cl: 1.21-12.55)) or 30-49 years (aPR: 4.83 (95\% Cl: 1.48-15.74)) compared to those aged under 20 (Table 3).

\section{Table 3}

Univariate and multivariate analysis of current HBV infection (positive HBsAg) according to sociodemographic characteristics in the 15-69-year-old general population living in Mayotte, Unono Wa

Maore, $2018-2019\left(n=2,916^{1}\right)$

\begin{tabular}{|c|c|c|c|c|c|c|}
\hline & \multicolumn{3}{|c|}{ Univariate analysis } & \multicolumn{3}{|c|}{ Multivariate analysis } \\
\hline & PR & $95 \% \mathrm{Cl}$ & $P$ value & aPR & $95 \% \mathrm{Cl}$ & $P$ value \\
\hline Gender & 1.00 & $1.37-3.96$ & 0.002 & 1.00 & $1.38-4.00$ & 0.002 \\
\hline Women & 2.33 & & & 2.35 & & \\
\hline \multicolumn{7}{|l|}{ Men } \\
\hline Age (years) & 1.00 & $0.50-1.96$ & 0.980 & 1.00 & $1.21-12.55$ & 0.023 \\
\hline $15-19$ & 0.99 & $1.11-3.41$ & 0.021 & 3.89 & $1.48-15.74$ & 0.009 \\
\hline $20-29$ & 1.94 & $0.36-1.85$ & 0.628 & 4.83 & $0.67-11.71$ & 0.156 \\
\hline $30-49$ & 0.82 & & & 2.81 & & \\
\hline \multicolumn{7}{|l|}{$50-69$} \\
\hline Place of residence & 1.00 & $0.65-1.80$ & 0.756 & & & \\
\hline West-Centre & 1.08 & $0.40-2.27$ & 0.919 & & & \\
\hline Dembeni-Mamoudzou & 0.96 & $0.63-2.25$ & 0.598 & & & \\
\hline North & 1.19 & $0.62-3.47$ & 0.377 & & & \\
\hline Petite-Terre & 1.47 & & & & & \\
\hline \multicolumn{7}{|l|}{ South } \\
\hline Educational level & 1.00 & $0.80-2.65$ & 0.222 & & & \\
\hline No diploma & 1.45 & $0.45-2.95$ & 0.769 & & & \\
\hline $\begin{array}{l}<\text { Secondary school certificate } \\
\geq \text { Secondary school certificate }\end{array}$ & 1.15 & & & & & \\
\hline Precarious housing & 1.00 & $0.45-1.32$ & 0.348 & & & \\
\hline No & 0.77 & & & & & \\
\hline \multicolumn{7}{|l|}{ Yes } \\
\hline Living in couple & 1.00 & $1.18-3.51$ & 0.010 & 1.00 & $0.69-2.50$ & 0.402 \\
\hline No & 2.04 & & & 1.32 & & \\
\hline Yes & & & & & & \\
\hline${ }^{1} \mathrm{HBs} A \mathrm{~g}$ result missing for one & on. & & & & & \\
\hline
\end{tabular}


aPR: adjusted prevalence ratio; PR: prevalence ratio, $\mathrm{Cl}$ : confidence interval

Numbers in bold indicate the significant associations in multivariate analysis.

Epidemiological and virological characteristics as well as comorbidities of people with a current HBV infection are presented in Table 4. 
Epidemiological and virological characteristics and comorbidities of HBsAg positive people (compared to those negative) in the 15-69-year-old general population living in Mayotte, Unono Wa Maore, 2018-2019

\begin{tabular}{|c|c|c|c|}
\hline & $\begin{array}{l}\text { HBsAg positive } \\
(n=76)\end{array}$ & $\begin{array}{l}\text { HBsAg negative } \\
(n=2,840)\end{array}$ & P value* \\
\hline \multicolumn{4}{|l|}{ Epidemiological characteristics } \\
\hline Men & $66.5 \%$ & $45.3 \%$ & 0.001 \\
\hline Age (years) & $4.4 \%$ & $18.8 \%$ & 0.021 \\
\hline $15-19$ & $23.8 \%$ & $24.0 \%$ & \\
\hline $20-29$ & $59.8 \%$ & $42.8 \%$ & \\
\hline $30-49$ & $12.0 \%$ & $14.4 \%$ & \\
\hline \multicolumn{4}{|l|}{$50-69$} \\
\hline Place of birth ${ }^{1}$ & $50.8 \%$ & $42.2 \%$ & 0.743 \\
\hline Mayotte & $44.3 \%$ & $49.6 \%$ & \\
\hline Comoros & 0 & $1.8 \%$ & \\
\hline France excluding Mayotte & $4.9 \%$ & $6.4 \%$ & \\
\hline \multicolumn{4}{|l|}{ Other countries } \\
\hline Educational level & $69.1 \%$ & $61.4 \%$ & 0.460 \\
\hline No diploma 2 & $20.7 \%$ & $27.1 \%$ & \\
\hline$<$ Secondary school certificate & $10.2 \%$ & $11.5 \%$ & \\
\hline \multicolumn{4}{|c|}{ Secondary school certificate or higher } \\
\hline Health insurance coverage ${ }^{1}$ & $22.8 \%$ & $36.9 \%$ & 0.244 \\
\hline None & $62.3 \%$ & $55.9 \%$ & \\
\hline Social security only & $14.9 \%$ & $7.2 \%$ & \\
\hline \multicolumn{4}{|c|}{ Social security and complementary insurance } \\
\hline Precarious housing & $51.4 \%$ & $57.9 \%$ & 0.346 \\
\hline Living in couple & $73.1 \%$ & $56.7 \%$ & 0.009 \\
\hline Lifetime sexual relations ${ }^{1}$ & $92.3 \%$ & $82.6 \%$ & 0.199 \\
\hline
\end{tabular}

* Chi-2 test; the distributions are significantly different for numbers in bold.

Ab: antibodies, HBeAg: HBe antigen; HBsAg: HBs antigen; HBV: Hepatitis B virus; HCV: Hepatitis C virus; HDV: Hepatitis $D$ virus

${ }^{1}$ These questions were only included in the long questionnaire $(n=1,505)$.

${ }^{2}$ People who answered "other" or did not answer were grouped with those who answered "no diploma."

${ }^{3}$ Among individuals who reported having sexual relations in their lifetime. 


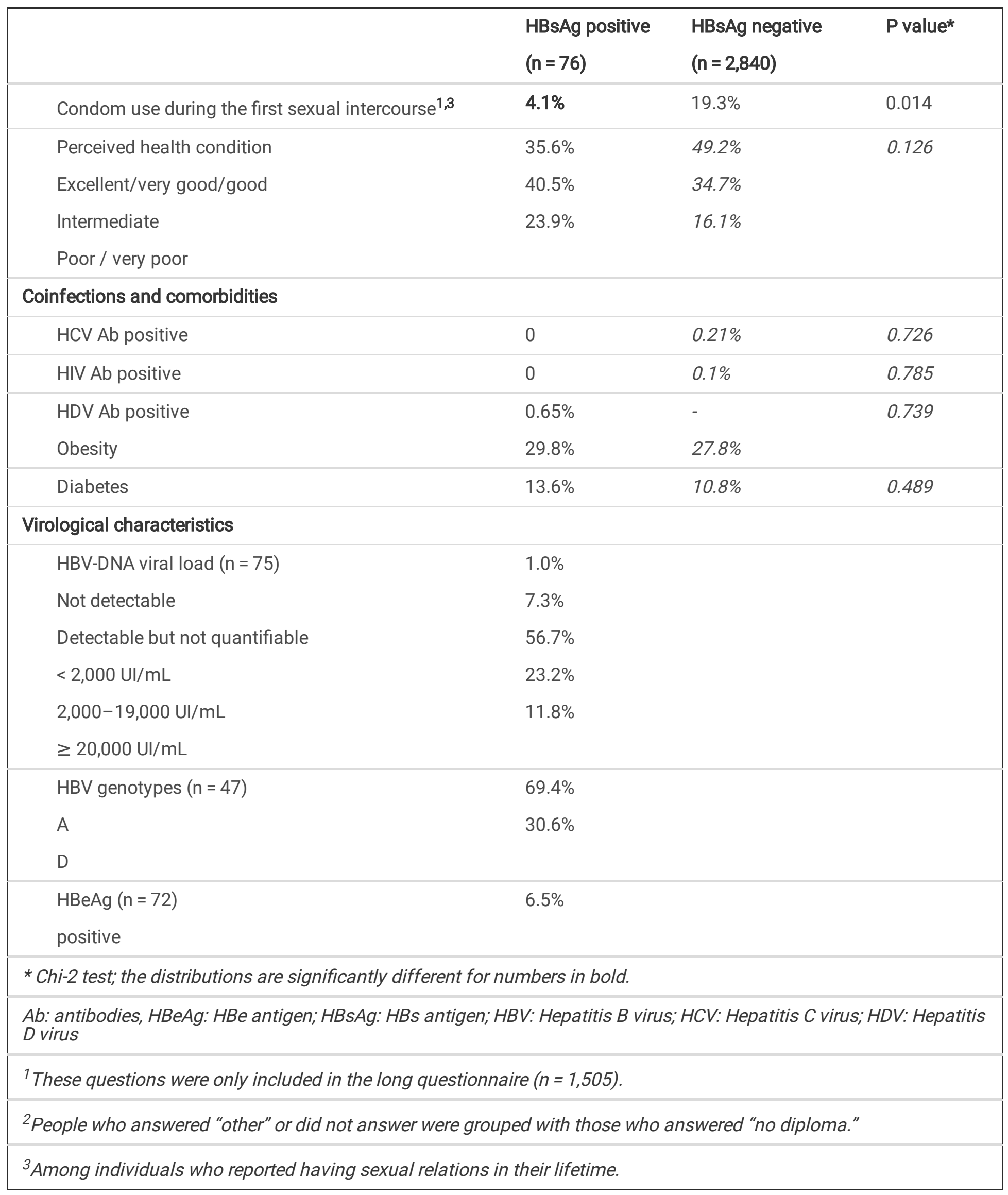


Almost $30 \%$ were obese and $13.6 \%$ presented diabetes, although these comorbidities were not related to HBsAg status. None were co-infected with HIV or HCV. Almost all were HBeAg negative (93.5\%). The HBV-DNA viral load (detectable for $99 \%$ ) was less than $2,000 \mathrm{IU} / \mathrm{ml}$, between 2,000 and $20,000 \mathrm{IU} / \mathrm{mL}$, and greater than $20,000 \mathrm{IU} / \mathrm{mL}$ for $64.0 \%, 23.2 \%$, and $11.8 \%$ of people, respectively. The HBV genotypes were A (69.4\%) and D (30.6\%). Only one person was positive for HDV antibodies $(0.65 \%)$, with an undetectable RNA HDV. Twelve participants reported that a doctor had diagnosed them with hepatitis B among the $34 \mathrm{HBsAg}(+)$ individuals (32.1\%) who answered the question in the long questionnaire.

\section{Resolved HBV infection}

The proportion of the population living in Mayotte aged 15-69 years with a resolved HBV infection was estimated at 27.8\% (95\% Cl: 25.8-28.9). This proportion varied significantly according to the studied characteristics with the exception of health insurance coverage, reported anti-HBV vaccination status, and precarious housing (Fig. 2). More specifically, this proportion was higher in men $(31.9 \%)$ than in women $\left(24.3 \%, p<10^{-3}\right)$ as well as in participants born in the Comoros (33.1\%) than in Mayotte (21.5\%), France (excluding Mayotte) (3.5\%), or another country (22.3\%). The proportion of those with a resolved HBV infection reached $50.5 \%$ among $50-69$ year-old participants.

\section{Lifetime HBV infection}

The estimated proportion of people living in Mayotte aged 15-69 years who had been infected with HBV during their lifetime (regardless of whether the infection was resolved or current) was 30.8\% (95\% Cl: 28.7-32.9). In multivariate analysis, the risk of lifetime HBV infection was significantly higher in men (aPR: 1.55 (95\% Cl: 1.29-1.86)) and in people aged 30-49 (aPR: 3.83 (95\% Cl: 1.49-9.81)) or 50-69 years (aPR: 4.52 (95\% Cl: 1.77-11.53)) compared to those aged under 20 (Table 5). 
Table 5

Univariate and multivariate analysis of lifetime HBV infection (resolved or current infection) according to sociodemographic and epidemiological characteristics in the 15-69 year-old general population living in Mayotte, Unono Wa Maore, 2018-2019 (analysis restricted to respondents to the long questionnaire, $n=1,505$ )

\begin{tabular}{|c|c|c|c|c|c|c|}
\hline & \multicolumn{3}{|c|}{ Univariate analysis } & \multicolumn{3}{|c|}{ Multivariate analysis } \\
\hline & PR & $95 \% \mathrm{Cl}$ & $P$ value & aPR & $95 \% \mathrm{Cl}$ & $P$ value \\
\hline Gender & 1.00 & $1.30-1.91$ & 0.000 & 1.00 & $1.29-1.86$ & 0.000 \\
\hline Women & 1.58 & & & 1.55 & & \\
\hline \multicolumn{7}{|l|}{ Men } \\
\hline Age (years) & 1.00 & $0.40-0.76$ & 0.000 & 1.00 & $0.80-5.25$ & 0.136 \\
\hline $15-19$ & 0.55 & $1.51-2.23$ & 0.000 & 2.05 & $1.49-9.81$ & 0.005 \\
\hline $20-29$ & 1.83 & $1.48-2.17$ & 0.000 & 3.83 & $1.77-11.53$ & 0.002 \\
\hline $30-49$ & 1.79 & & & 4.52 & & \\
\hline \multicolumn{7}{|l|}{$50-69$} \\
\hline Place of birth & 1.00 & $1.21-1.80$ & 0.000 & 1.00 & $0.92-1.41$ & 0.249 \\
\hline Mayotte & 1.48 & $0.43-0.97$ & 0.036 & 1.13 & $0.37-0.86$ & 0.009 \\
\hline Comoros & 0.65 & & & 0.57 & & \\
\hline \multicolumn{7}{|c|}{ France (excluding Mayotte) or other countries } \\
\hline Place of residence & 1.00 & $1.07-1.57$ & 0.008 & 1.00 & $1.09-1.80$ & 0.008 \\
\hline West-Centre & 1.30 & $0.52-1.04$ & 0.081 & 1.40 & $0.70-1.53$ & 0.870 \\
\hline Dembeni-Mamoudzou & 0.74 & $0.94-1.53$ & 0.138 & 1.03 & $0.98-1.74$ & 0.066 \\
\hline North & 1.20 & $0.62-1.26$ & 0.487 & 1.31 & $0.76-1.57$ & 0.643 \\
\hline Petite-Terre & 0.88 & & & 1.09 & & \\
\hline \multicolumn{7}{|l|}{ South } \\
\hline Educational level & 1.00 & $0.40-0.71$ & 0.000 & 1.00 & $0.76-1.31$ & 0.986 \\
\hline No diploma & 0.53 & $0.62-1.20$ & 0.377 & 0.99 & $0.77-1.46$ & 0.718 \\
\hline$<$ Secondary school certificate & 0.86 & & & 1.06 & & \\
\hline \multicolumn{7}{|l|}{$\geq$ Secondary school certificate } \\
\hline Precarious housing & 1.00 & $0.79-1.17$ & 0.681 & & & \\
\hline No & 0.96 & & & & & \\
\hline \multicolumn{7}{|l|}{ Yes } \\
\hline Living in couple & 1.00 & $1.52-2.34$ & 0.000 & 1.00 & $0.81-1.21$ & 0.929 \\
\hline No & 1.88 & & & 0.99 & & \\
\hline Yes & & & & & & \\
\hline
\end{tabular}




\begin{tabular}{|lrrrrrr|}
\hline & \multicolumn{3}{c|}{ Univariate analysis } & \multicolumn{3}{c|}{ Multivariate analysis } \\
\hline Condom use during first sexual intercourse & 1.00 & $2.19-4.72$ & 0.000 & 1.00 & $\mathbf{1 . 0 1 - 2 . 1 4}$ & $\mathbf{0 . 0 4 6}$ \\
Yes & 3.22 & $0.43-0.99$ & 0.044 & $\mathbf{1 . 4 6}$ & $0.21-1.49$ & 0.242 \\
& 0.65 & & & 0.56 & & \\
No / Not specified & & & & & & \\
No sexual relations in the lifetime & & & & & & \\
\hline
\end{tabular}

aPR: adjusted incidence rate ratio; PR: incidence rate ratio, Cl: confidence interval Numbers in bold indicate the significant associations in multivariate analysis.

In univariate analysis, individuals born in the Comoros were more likely to have been infected during their lifetime than those born in Mayotte, but this association was no longer statistically significant in multivariate analysis. The risk of lifetime HBV infection was lower for individuals born in France (excluding Mayotte) or in other countries (aPR: 0.57 (95\% Cl: 0.37-0.86) compared to those born in Mayotte. People living in Dembeni-Mamoudzou (aPR: 1.40 (95\% Cl: 1.09-1.80)) had a higher risk of having been infected compared to those living in the West-Centre of Mayotte, as well as those living in Petite-Terre though it was not statistically significant. Regarding sexual behaviour, the risk of having been infected with HBV was significantly higher in individuals who reported not using a condom during their first sexual intercourse (aPR: 1.46 (95\% Cl: 1.01-2.14)) compared to those who declared using one.

\section{Immunisation by vaccination}

The proportion of people immunised by vaccination in the 15-69-year-old population living in Mayotte was estimated at 27.7\% (95\% Cl: 25.9-29.7) and varied significantly according to the investigated variables (Fig. 2). In particular, this proportion was higher among those with self-reported vaccination against HBV (40.5\%) than those declaring to be unvaccinated (14.1\%) or not knowing (23.6\%). It reached $37.9 \%$ among those under 30 years.

\section{No infection / no immunisation}

More than four in ten people in the general adult population (41.5\% (95\% Cl: 39.3-43.7)) were estimated to be negative for all three serological markers and therefore susceptible to infection with HBV and HDV. This proportion reached $47.9 \%$ among those under 30 years and $51.3 \%$ among those who reported no sexual intercourse in their lifetime.

\section{Hepatitis C}

Among the 2,917 people screened for HCV antibodies, only six were positive (0.21\%). These three men and three women had an average age of 56.3 years $(\min =33, \max =66$ ). Three people had an active HCV infection (HCV RNA positive), with HCV RNA levels of 4.7, 5 and 5.2 Log IU/mL, respectively. Hepatitis C genotype was $1 \mathrm{~b}, 3 \mathrm{~h}$, and 2 (not subtypable).

\section{Discussion}

This survey conducted among a large random sample of the general population living in Mayotte enabled us to provide original and robust estimates of hepatitis $\mathrm{B}, \mathrm{C}$, and delta prevalence and the distribution of HBV infection status, to identify the determinants of HBV infection and to describe the epidemiological and virological characteristics of people infected with HBV.

Current HBV infection prevalence was estimated to be $3.0 \%$ (95\% Cl: 2.3-3.9) in 15-69 year-olds, corresponding to a prevalence 10 times higher than that estimated in the general population in mainland France in $2016(0.3 \%)$ [19]. This is consistent with previous estimates that focussed on specific populations such as pregnant women (2.3-4.8\%) [11-14], 
hospitalised patients (4.3\%) [15], and people tested at the CHM laboratory (3.8\%) [16] or in anonymous free testing consultations (4.5\%) [14]. Our findings confirm that Mayotte is an area of intermediate endemicity for HBV. The results also highlight that men were more affected by HBV with an estimated prevalence of $4.3 \%$, which is more than twice as high as that estimated in women (1.9\%), while they also had a significantly higher risk of being infected regardless of their other characteristics. Men should therefore constitute a target population for HBV testing. Indeed, with a high fertility rate (5.0 children per woman) [2] and a high rate of prenatal screening for hepatitis B (96.4\%) [12] (mandatory since 1992), HBV testing may not be a pressing issue in women. Furthermore, testing is even more important, as nearly three quarters of people testing positive for HBsAg declared that they were living with a partner, with a risk of transmission to their spouse and children. The estimated proportion of HBsAg positive people indicating that a doctor had told them that they had hepatitis $B(32 \%)$ should be interpreted with caution due to the small numbers of respondents and the fact that the question may have been misunderstood during the interview. In terms of age, the highest prevalence was observed among 30-49 year-olds (4.1\%), although it exceeded $2 \%$ in the other age groups except for $15-19$ year-olds (0.7\%). Indeed, more than $80 \%$ of 15-19 year-olds were born in Mayotte and were therefore eligible for HBV vaccination at birth, a policy that was implemented at CHM in 1999 and officially recommended in Mayotte in 2012 [14, 20]. This was not the case with 2029 year-olds given that they were born before 1999 and mostly in the Comoros (almost 60\%) [21]. In multivariate analysis, people of this age group were at a higher risk of having a current HBV infection compared to the youngest age group and the 30-49 age group. It should nevertheless be noted that multivariate analysis could not take into account the place of birth as it would have resulted in the loss of statistical power, since this information was only provided by people who answered the long questionnaire.

Our results suggest that the transmission modes of HBV are varied and that contamination occurs at all ages, as classically described in areas of intermediate HBV endemicity. Indeed, $1.3 \%$ of people who declared no sexual intercourse were positive for HBsAg, thus suggesting perinatal or childhood transmission. Conversely, the five times higher prevalence among people who declared not using a condom during their first sexual intercourse points toward sexual transmission. The heterogeneity of the population living in Mayotte, with more than half of adults born abroad [2], mainly in the Comoros where the health and social context is particularly unfavourable [22], also probably contributes to this variability regarding HBV transmission. Even if the economic situation is more privileged in Mayotte compared to the Comoros, it is important to note that more than a third of the population is estimated to lack health insurance coverage according our results (this proportion was 32.4\% in 2019 according to the Mayotte Social Security Fund [23]). This proportion was estimated at $23 \%$ among people positive for HBsAg, with a possible impact on screening and management. It should be noted that state medical aid, a specific French health insurance coverage for irregular migrants, does not exist in Mayotte, where only legal residents can be insured. This is an issue for health care access, since half of residents of foreign nationality were in an irregular situation in 2015 [21].

In terms of comorbidities, no cases of co-infection with HIV or HCV were identified, reflecting the limited circulation of these viruses in Mayotte and more widely in the Comoros archipelago [24], probably linked to the low frequency of injecting drug use and sex between men [11]. The proportion of diabetes (14\%) and obesity (30\%) was high in HBsAg positive people (also in those who were negative), thus constituting additional risk factors for progression to cirrhosis or liver cancer [25]. Regarding virological characteristics, the proportion of people with HBV DNA level $>20,000 \mathrm{IU} / \mathrm{mL}$ (11.8\%), positive HBeAg (6.5\%) or positive HDV antibodies (0.65\%) was lower than observed in patients treated in expert hepatology wards in France between 2008 and 2012 (22.2\%, 12.2\%, and 3.7\%, respectively), as these services generally care for severe patients with more advanced liver disease [26]. The HBV genotypes identified (A and D) correspond to those circulating in Africa, especially in East Africa [27].

The proportion of people with a resolved HBV infection was estimated at $27.8 \%$ (95\% Cl: 25.8-29.9), increasing sharply with age to reach 51\% among 50-69 year-olds. Consequently, more than three in ten people aged 15-69 years living in Mayotte have a lifetime HBV infection (resolved or current). As expected, the risk of lifetime HBV infection in multivariate

Page $15 / 21$ 
analysis was significantly higher in men and in people over 30 years (compared to those under 20). More surprisingly, compared to those born in Mayotte, people born in the Comoros were more likely to have been infected during their lifetime in univariate analysis, but this association was not statistically significant after adjustment to other variables, especially gender and age group, in multivariate analysis. This could be explained by significant differences between the age and sex distributions of people born in Mayotte and the Comoros, whereas the proportion of infected people varied greatly according to gender and age group [2]. The risk of lifetime HBV infection was higher in the areas of DembeniMamoudzou and Petite-Terre (though not significant for the latter) compared to the West-Centre of Mayotte in multivariate analysis. These areas are characterised by the highest proportions of people born in the Comoros (respectively $58 \%$ and $54 \%$ vs $42 \%$ in the rest of the island). After adjusting to other variables, this association, especially place of birth, suggests a higher past or current circulation of HBV in these areas, regardless of the place of birth. Finally, a significant association between condom non-use and risk of lifetime HBV infection was observed, as previously shown in pregnant women by Saindou et al. [28].

In this context of significant HBV circulation, the implementation of preventive measures, in particular vaccination, is essential. While the implementation of anti-HBV vaccination at birth $[14,20]$ since 1999 has made it possible to achieve high levels of vaccination coverage in children (95\% in children aged $24-59$ months) and adolescents (75\% in 14-15 year-olds) [10], which are greater than for other vaccinations [29], HBV vaccination coverage still needs to be enhanced. Thus, only $37 \%$ of young people aged 15 to 19 years at the beginning of their sexual life presented a serological profile indicating immunisation by vaccination. This proportion remains insufficient even considering the possible loss of HBs antibodies, estimated to concern about $40-45 \%$ of adolescents vaccinated at birth [30]. Indeed, it has been shown that protection persists for at least 30 years or even throughout life, even in the case of disappearing HBs antibodies [31]. The determinants of immunisation by HBV vaccination, which would be useful to guide the implementation of a potential new vaccination catch-up campaign as previously performed in 2018 [29], will be the subject of a specific article.

Besides the insufficient immunisation rate, the vaccine status against HBV was poorly known by participants, since more than half of the population in Mayotte was estimated to be unaware of their HBV vaccine status. In mainland France, this estimated proportion was 7\% in 2016 [19]. Among people declaring to be vaccinated, $2.4 \%$ were estimated to be HBsAg positive and therefore at risk of transmitting the infection in a context of probably insufficient preventive sexual behaviours. Thus, only $19.5 \%$ of people indicated using a condom at their first sexual intercourse. This proportion was estimated to be $35.2 \%$ among 18-29 year-olds living in Mayotte (data not shown) versus $85 \%$ in the same population in mainland France in 2016 [32].

For hepatitis $\mathrm{C}$ virus, only six of the 2,917 people tested for HCV antibodies were positive $(0.21 \%)$, including three positive for HCV RNA. This result confirms that Mayotte is a low endemic area for HCV, similarly to mainland France where the prevalence of HCV RNA was estimated at $0.3 \%$ among the general population in 2016 [19].

As the objective of the Unono Wa Maore survey was to describe the state of health and health care use for the population living in Mayotte, choices were made to limit the length of time for completing the questionnaires. Thus, the epidemiological data collected on hepatitis were limited and only appeared in the long questionnaire (e.g., questions on country of birth or sexuality). Therefore, this limited the power of the statistical analyses. Further, comparisons with the results of other health surveys performed in mainland France $[19,32]$ must be interpreted with caution given the methodological differences and the cultural specificities of the population living in Mayotte. Finally, due to difficulties relating to the context of the survey, not all respondents could have a blood sample and thus be screened for HBV and HCV. However, thanks to a very high participation rate in the survey (89\%), nearly 3,000 people, or almost $2 \%$ of all residents aged 15-69 years, were tested for HBV and HCV. Their characteristics were close to those of all participants after weighting and adjustment. The implementation of the survey, directly in the homes of participants, also made it possible to take venous blood samples to search for numerous serological and molecular markers of hepatitis B, C, and delta.

Page $16 / 21$ 


\section{Conclusions}

This survey conducted among a large random sample of the general adult population confirmed that Mayotte is an area of intermediate endemicity for HBV and low endemicity for HCV and HDV. With a prevalence of HBsAg 10 times higher than in mainland France, a high proportion of unimmunised people, especially young people, and a demographic, health, and social context that may favour its transmission, hepatitis B should be considered as a public health priority in Mayotte. In this perspective, implementing vaccination catch-up campaigns in adolescents and young adults, strengthening screening for hepatitis B in men, as well as promoting preventive sexual behaviours are among the priority actions to be carried out.

\section{Abbreviations}

$\mathrm{Ab}$

antibodies

$\mathrm{Cl}$

confidence interval

HBsAg

HBs antigen

HBV

hepatitis $B$ virus

$\mathrm{HCV}$

hepatitis $C$ virus

HDV

hepatitis $D$ virus

PR

prevalence ratio

\section{Declarations}

\section{Ethics approval and consent to participate}

The research protocol (including the experimental protocol) was validated by the Committee for the Protection of Persons (CPP, no. 2017-A02782-51), the French ethical committee for biomedical research, and complied with MR001 reference methodology (agreement from the National Commission for Informatics and Freedoms of 25 September 2018, no. 918233). Information on the survey objectives and consent forms were read with the participants. A written informed consent was obtained from all participants, or if participants were under 15 , from a parent and/or legal guardian. , who gave their written consent.

All methods were carried out in accordance with relevant guidelines and the Declaration of Helsinki.

\section{Consent for publication}

Not applicable.

\section{Availability of data and materials}

The dataset analysed during the current study is available from the corresponding author on reasonable request. The dataset is not publicly available because this survey was funded by two different institutions. 


\section{Competing interests}

The authors declare that they have no competing interests.

\section{Funding}

This study was funded by the French National Public Health Agency (Santé publique France) and the Mayotte Regional Health Agency.

\section{Authors' contributions}

The members of the Unono Wa Maore group participated in the design and the implementation of the Unono Wa Maore survey (MR, MF, JBR, JLS, HY) and/or in the preparation of the database (MR, JBR, DJS, JC). MR and HY coordinated the survey. MR and CB organised the transportation of blood samples from Mayotte to mainland France. SC and EG coordinated the blood sample analysis for the samples found positive for HBs antigen or HCV antibodies in the Mayobio laboratory. CB conducted the data analysis. CB conducted the literature review and wrote the manuscript. All authors commented on the manuscript and approved the final version.

\section{Acknowledgements}

We are grateful to the people who participated in the Unono Wa Maore survey; the Santé publique France teams, particularly the regional offices in Mayotte and Reunion; the Mayotte regional health agency; the National Reference Centre for Hepatitis B, C, and Delta; the IPSOS Observer and Sikajob Institutes; the investigators; the nurses of the Regional Union of Health Professionals of the Indian Ocean; the Mayobio laboratory, pharmacies, and Mayotte hospital; and all the people who contributed to this survey. Finally, we give our thanks to Victoria Grace for the English editing of the manuscript.

The Unono Wa Maore group is composed of Marc Ruello, Marion Fleury, Jean-Baptiste Richard, Jean-Louis Solet, Laurent Filleul, Delphine Jezewski-Serra, Julie Chesneau, and Hassani Youssouf (Santé publique France).

\section{References}

1. Institut national de la statistique et des études économiques. Estimation de la population au 1er janvier 2021. Séries par région, département, sexe et âge de 1975 à 2021: INSEE; 2021. https://www.insee.fr/fr/statistiques/1893198

2. Chaussy C, Merceron S, Genay V. A Mayotte, près d'un habitant sur deux est de nationalité étrangère. 2019. p. https://www.insee.fr/fr/statistiques/3713016

3. Institut national de la statistique et des études économiques. Taux de natalité et âge moyen de la mère à la naissance en 2020, et nombre de naissances en 2019. Comparaisons régionales et départementales: Insee; 2021. https://www.insee.fr/fr/statistiques/2012761

4. Merceron S. Revenus et pauvreté à Mayotte en 2018, les inégalités de niveau de vie se sont creusées 2020. https://www.insee.fr/fr/statistiques/4622454

5. Anguis $\mathrm{M}$, Bergeat $\mathrm{M}$, Pisarik J, Vergier $\mathrm{N}$, Chaput $\mathrm{H}$. Quelle démographie récente et à venir pour les professions médicales et pharmaceutique? Constat et projections démographiques. Paris: Direction de la recherche, des études, de l'évaluation et des statistiques 2021. 74 p. https://drees.solidarites-sante.gouv.fr/sites/default/files/202103/DD76_0.pdf

6. Solet JL, Baroux N, Pochet M, Benoit-Cattin T, De Montera AM, Sissoko D, et al. Prevalence of type 2 diabetes and other cardiovascular risk factors in Mayotte in 2008: the MAYDIA study. Diabetes Metab. 2011;37(3):201-7. 
7. Ntab B, Gandin P, Castetbon K, Sissoko D, Vernay M. État nutritionnel et activité physique à Mayotte, France: premiers résultats de l'étude NutriMay 2006. Bulletin Epidémiologique Hebdomadaire. 2007(48-49):402-4.

8. Sissoko D, Moendandze A, Malvy D, Giry C, Ezzedine K, Solet JL, et al. Seroprevalence and risk factors of chikungunya virus infection in Mayotte, Indian Ocean, 2005-2006: a population-based survey. PLoS One. 2008;3(8):e3066.

9. Youssouf H, Subiros M, Dennetiere G, Collet L, Dommergues L, Pauvert A, et al. Rift Valley Fever Outbreak, Mayotte, France, 2018-2019. Emerg Infect Dis. 2020;26(4):769-72.

10. Solet JL, Baroux N, Lernout T, Filleul L, Petit A, de Montera AM, et al. Estimation of the immunization coverage in Mayotte in 2010. Open Public Health Journal. 2013;6:1-5.

11. Saindou M, Bénet T, Troalen D, Abaine A, Voirin N, Giard M, et al. Prevalence and risk factors for HIV, hepatitis B virus, and syphilis among pregnant women in Mayotte, Indian Ocean, 2008-2009. Int J Gynaecol Obstet. 2012;119(1):615 .

12. Brouard C, Koenig C, Bonnet C, Blondel B, Sommen C, Lot F. Prévention de la transmission mère-enfant du virus de I'hépatite B en France. Enquête nationale périnatale 2016. Bulletin Epidémiologique Hebdomadaire. 2020(31-32):612 $-23$.

13. Parenton F, Youssouf H, Mariotti É, Barbail A. La situation périnatale à Mayotte en 2016: principaux résultats de I'Enquête nationale périnatale (ENP) et de son extension. Bulletin Epidémiologique Hebdomadaire. 2020(1):17-27.

14. Muszlak M, Lartigau-Roussin C, Farthouat L, Petinelli M, Hebert JC, Santiago J. Vaccination of children against hepatitis B in Mayotte, French Comoros Island. Arch Pediatr. 2007;14(9):1132-6.

15. Michaud C, Vernier M, Ahmad D, Diallo A, Millot P, Olivier S, et al. Evaluation du dépistage systématique du VIH, des hépatites $B, C$ et de la syphilis dans un service de médecine ultramarin de juillet 2014 à juin 2015. Médecine et maladies infectieuses. 2016;46:50-7.

16. Pioche C, Léon L, Vaux S, Brouard C, Lot F. Dépistage des hépatites B et C en France en 2016, nouvelle édition de l'enquête LaboHep. Bulletin Epidémiologique Hebdomadaire. 2018(11):188-95.

17. Ruello M, Fleury M, Richard JB, Solet JL, Bonnave PE, Filleul L, et al. The 2019 Health Barometer in the general population of Mayotte, "Unono Wa Maore" health survey. (submitted).

18. Préfet de Mayotte. Les services de l'Etat à Mayotte. L'intercommunalité. https://www.mayotte.gouv.fr/Politiquespubliques/Amenagement-du-territoire-Politique-de-la-Ville-et-Cohesion-Sociale/L-intercommunalite

19. Brouard C, Saboni L, Gautier A, Chevaliez S, Rahib D, Richard JB, et al. HCV and HBV prevalence based on home blood self-sampling and screening history in the general population in 2016: contribution to the new French screening strategy. BMC Infect Dis. 2019;19(1):896.

20. Haut Conseil de la santé publique. Avis relatif à l'adaptation des recommandations et du calndrier vaccinal du département de Mayotte. Paris: HCSP; 2012. 5 p. https://www.hcsp.fr/explore.cgi/avisrapportsdomaine?clefr=254

21. Marie C-V, Breton D, Crouzet M, Fabre E, Merceron S. Migrations, natalité et solidarités familiales. La société de Mayotte en plien mutation 2017. p. https://www.insee.fr/fr/statistiques/2656589

22. Mohamed KS, Abasse KS, Abbas M, Sintali DN, Baig M, Cote A. An Overview of Healthcare Systems in Comoros: The Effects of Two Decades of Political Instability. Ann Glob Health. 2021;87(1):84.

23. Caisse de Sécurité Sociale de Mayotte. Les chiffres clés de la Caisse de Sécurité Sociale de Mayotte 2019. https://www.cssm.fr/uploads/espace\%20presse/Les\%20chiffres\%20cl\%C3\%A9s\%202019\%20de\%20la\%20CSSM.pdf

24. Dada Y, Milord F, Frost E, Manshande JP, Kamuragiye A, Youssouf J, et al. The Indian Ocean paradox revisited: HIV and sexually transmitted infections in the Comoros. Int J STD AIDS. 2007;18(9):596-600.

25. Younossi ZM, Henry L. Epidemiology of non-alcoholic fatty liver disease and hepatocellular carcinoma. JHEP Rep. 2021;3(4):100305. 
26. Santé publique France. Données de surveillance nationale de l'hépatite $B$ chronique à partir des pôles de référence et réseaux hépatites volontaires. https://www.santepubliquefrance.fr/maladies-et-traumatismes/hepatitesvirales/hepatites-b-et-d/articles/donnees-epidemiologiques-2008-2012

27. Tong S, Revill P. Overview of hepatitis B viral replication and genetic variability. J Hepatol. 2016;64(1 Suppl):S4-s16.

28. Saindou M, Voirin N, Troalen D, Abaine A, Chevallier-Queyron P, Ecochard R, et al. Socio-demographic and behavioral determinants of hepatitis $\mathrm{B}$ vaccination and infection in pregnant women on Mayotte Island, Indian Ocean. Vaccine. 2013;31(43):4946-52.

29. Subiros M, Barbail A, Larsen C. Évaluation épidémiologique de la campagne de rattrapage vaccinal chez les enfants de moins de 6 ans à Mayotte, mai-juin 2018 Saint-Maurice: Santé publique France; 2019. http://intradoc.ansp.local/exl-php/docs/spf__recherche/27271/spf00001115_PDF.txt

30. Schwarz TF, Behre U, Adelt T, Donner M, Suryakiran PV, Janssens W, et al. Long-term antibody persistence against hepatitis B in adolescents 14-15-years of age vaccinated with 4 doses of hexavalent DTPa-HBV-IPV/Hib vaccine in infancy. Hum Vaccin Immunother. 2019;15(1):235-41.

31. Haut Conseil de la santé publique. Vaccination contre l'hépatite B: problématique des non-répondeurs. Paris: HCSP; 2014. 27 p. https://www.hcsp.fr/Explore.cgi/avisrapportsdomaine?clefr=475

32. Bajos N, Rahib D, Lydié N. Genre et sexualité. D'une décennie à l'autre. Baromètre santé 2016. Saint-Maurice: Santé publique France; 2018. 6 p. https://www.santepubliquefrance.fr/determinants-de-sante/santesexuelle/documents/enquetes-etudes/barometre-sante-2016.-genre-et-sexualite

\section{Figures}

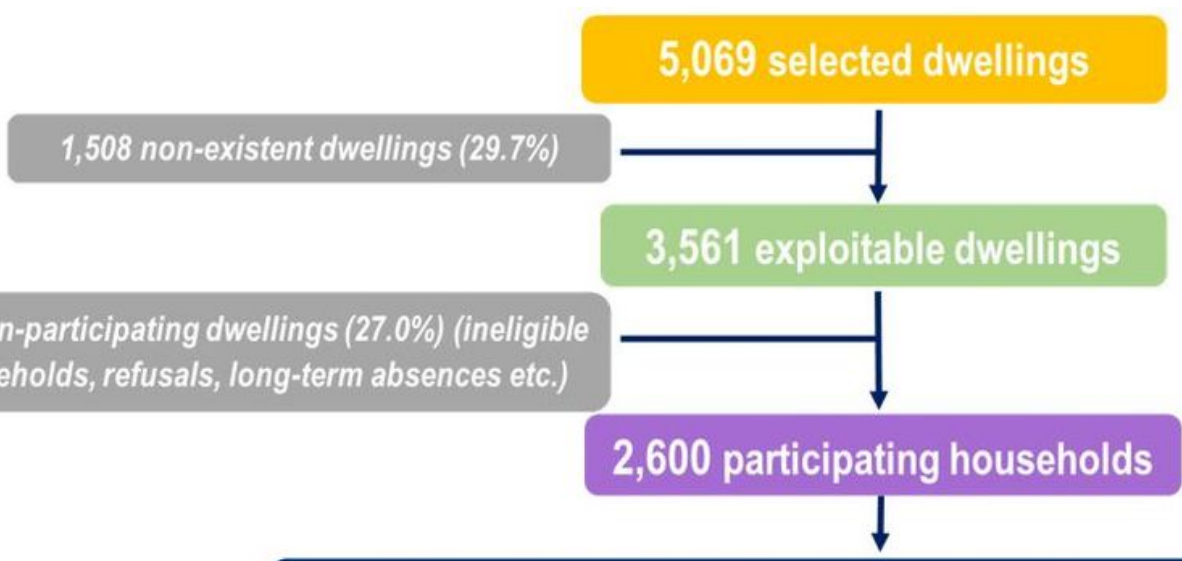

\section{5,207 individuals aged $15-69$ years invited to participate}

2,248 short questionnaires

1,412 short questionnaires
4,643 respondents to the

questionnaire $(89.2 \%)$

1

2,917 individuals screened for HBV / HCV (62.8\%)
2,395 long questionnaires

1,505 long questionnaires

Figure 1

Flow-chart, Unono Wa Maore, Mayotte, 2018-2019

Page 20/21 


\section{Figure 2}

HBV virological status in the 15-69-year-old general population living in Mayotte, Unono Wa Maore, 2018-2019

* $P$ value $<0.05 ; * \star P$ value $<10^{-2}$; ${ }^{* \star} P$ value $<10^{-3}$ for the Chi-2 test comparing HBV infection status (four modalities) according to the different qualitative variables.

Only the long questionnaire included the variables of place of birth, health insurance coverage, lifetime sexual relations, condom use at first sexual intercourse, and perceived health condition. 